\title{
United by grass, separated by coal: Uruguay and New Zealand during the First Globalization ${ }^{\dagger}$
}

\author{
Emiliano Travieso \\ King's College, Cambridge, CB2 1ST, United Kingdom \\ Corresponding author. E-mail: et399@cam.ac.uk
}

\begin{abstract}
While the role of coal has been the subject of long-running debate in the historiography of the Industrial Revolution, its part in the economic development of the global periphery has been comparatively neglected. The technological context of the 'First Globalization' (c.1870-1914) made pastoral production in the periphery increasingly dependent on modern energy, as new methods of production and transportation bridged the distance between grasslands in the south of the world and kitchens in the north. By comparing choices of meat preservation techniques in Uruguay and New Zealand - two small settler economies that prospered on the back of pastoral exports - this article highlights the usefulness of an energy perspective on agriculture-based transitions to modern economic growth. Different conditions of access to coal shaped how New Zealanders and Uruguayans exploited their livestock herds when terms of trade favoured them the most, with important consequences for the persisting income gap between them.
\end{abstract}

Keywords: comparative history; energy; First Globalization; livestock; settler economy

\section{Introduction}

The technologies of meat preservation - extraction, canning, and refrigeration - were crucial contributions to the process of trade expansion, price convergence, and market integration known as the 'First Globalization' (c.1870-1914). Albeit with different intensity, all these technologies required large supplies of energy, which before the development of hydropower and national electrical grids meant that they relied heavily on coal. Export-led growth in some of the so-called 'settler economies' was to a large extent made possible by these new technologies, and by steamship and railroad transportation, themselves coal-powered innovations. ${ }^{1}$ This article compares the cases of New Zealand and Uruguay, two small agriculture-based settler economies of the southern hemisphere, showing how their late nineteenth-century export-led growth was similarly dependent on coal, but crucially differentiated by its price. While both societies became very prosperous

\footnotetext{
${ }^{\dagger}$ Earlier versions of this article were presented to seminars in 2016-17 at Cambridge, at the Universidad de la República (Uruguay), and at the RIDGE Economic History Workshop in Montevideo. I am very grateful to the organizers and for all the contributions from participants. Particular thanks are due to scholars who commented separately: Jorge Álvarez, Gareth Austin, Reto Bertoni, William G. Clarence-Smith, Juan Infante-Amate, Ellen Carmen Gordon, Tom Westland, Paul Warde, and this journal's anonymous readers. Sofia Teives Henriques generously shared her data on Denmark. Funding from the Cambridge International Trust is gratefully acknowledged. Special thanks also to Mauro Delgrosso and Fabiana Villalba at the Museo de la Revolución Industrial in Fray Bentos (Uruguay). Any mistakes are mine.

${ }^{1}$ A classic comparative history of 'settler economies' encompassing Argentina, Australia, New Zealand, South Africa, and Uruguay is Donald Denoon, Settler capitalism: the dynamics of dependent development in the southern hemisphere, Oxford: Clarendon Press, 1983. For a more recent assessment of the concept, see Christopher Lloyd and Jacob Metzer, 'Settler colonization and societies in world history: patterns and concepts', in Christopher Lloyd, Jacob Metzer, and Richard Sutch, eds., Settler economies in world history, Leiden: Brill, 2013, pp. 1-34.

(C) The Author(s), 2020. Published by Cambridge University Press. This is an Open Access article, distributed under the terms of the Creative Commons Attribution licence (http://creativecommons.org/licenses/by/4.0/), which permits unrestricted re-use, distribution, and reproduction in any medium, provided the original work is properly cited.
} 
by the standards of non-industrialized countries, New Zealand became significantly richer than Uruguay, and has remained ahead by much the same margin, more or less to the present day.

Trying to explain that gap, economic historians have often pointed to New Zealand's precocity, and Uruguay's tardiness, in adopting innovations in pastoral production, particularly in developing a dairy and refrigerated meat export trade. ${ }^{2}$ Rather than this being only or fundamentally a result of different institutional contexts encouraging or stifling innovation in manufacturing, I argue that the complicated processes associated with the adoption of refrigeration were grounded in the different material realities of livestock production. ${ }^{3}$ In particular, the different cost of energy in the two economies had important implications for the choices of technique by the respective producers.

New Zealand first exported frozen mutton in 1882, and soon after almost all of its meat exports were frozen or chilled, whereas Uruguay, which had larger livestock herds, only started exporting chilled meat twenty-five years later, and predominantly exported salted and cured beef until 1913. One could say that the difference was a matter of taste, but one with powerful economic consequences. European consumers preferred beef and mutton fresh, and the increasingly numerous workingclass consumers of New Zealand and Uruguayan produce wanted meat as close to fresh as they could afford, unlike pork, which they particularly enjoyed salted or cured (as in bacon, ham, and sausages). Refrigerated beef and mutton were the superior products, and could command higher prices; in economic terms, they had a much higher income elasticity of demand than beef jerky or corned beef. In this context, a reciprocal comparison of the meat industries of New Zealand and Uruguay allows us to tell the story of two societies united by grass but separated by coal, which developed along different routes of specialization, despite having similar resources of agricultural land.

Offering new evidence on coal prices and firm-level coal use, this article considers the impact of fuel markets in the choice of meat preservation techniques in New Zealand and Uruguay before the First World War. The discussion will hopefully be relevant beyond the histories of these two small countries, and indeed the history of meat as a commodity, in at least three respects. First, on the question of energy and economic development set against the background of the Great Divergence in global economic history, the article provides a comparative study of coal's part in differentiating two growth stories in the periphery. Second, regarding the debates on the impact of fossil fuel use on the energy balance of agriculture in environmental history, the New Zealand and Uruguayan experiences illustrate the importance of considering energy inputs beyond farms. Even if livestock raising remained an activity based on the traditional, renewable, energies at play in the grasslands, the processing of meat on the killing floor and beyond became increasingly dependent on fossil fuels, which had important economic and ecological consequences. Third, whereas most studies of the divergent fortunes of settler societies contrast the similarity of natural environments and resource constraints with the differences in social structures and institutional contexts, this article emphasizes the importance of considering the specificity of natural resources, and their impact on the economic costs and material realities of production. In so doing, it suggests that distinguishing between different kinds of natural resource, and considering their combinations in particular historical contexts as well, can prove more useful to economic and environmental historians than concentrating solely on aggregate measures of 'natural capital'.

After this introduction, the first section reviews the arguments for and against coal as a key factor in the onset of modern economic growth, trying to transcend the divide between the debates centred on the industrialized West and cases in the global periphery. The second section frames the New Zealand/Uruguay comparison in a global context, and situates the present contribution in

${ }^{2}$ John Kirby, 'Uruguay and New Zealand paths to progress', Revista Geográfica, 107, 1988, pp. 119-49. For a recent overview, see Jorge Álvarez and Luis Bértola, 'So similar, so different: New Zealand and Uruguay in the world economy', in Lloyd, Metzer, and Sutch, Settler economies, pp. 493-520.

${ }^{3}$ For an economic model focusing on the link between institutional frameworks and the different development of agriculturally based manufacturing industries in New Zealand and Uruguay, see Jorge Álvarez, Ennio Bilancini, Simone D'Alessandro and Gabriel Porcile, 'Agricultural institutions, industrialization and growth: the case of New Zealand and Uruguay in 1870-1940', Explorations in Economic History, 48, 2, 2011, pp. 151-68. 
the comparative literature. The third section presents new estimates of coal supply and prices in both countries. The fourth section considers the relevance of coal-fuelled meat preservation in this period at the economy-wide level, while the fifth section compares the impact of coal prices on choices of techniques at a micro level, referring to individual companies in New Zealand and Uruguay.

\section{Coal and modern economic growth in global economic history}

Energy resources are a central part of many histories of the English Industrial Revolution. Largescale use of coal was the common denominator of the innovations that signalled the beginning of industrialization in late eighteenth-century England, which was, as described by Wrigley and Cipolla, an energy transition that freed human societies from the constraints of an 'organic economy' by giving them control over machines worked by inanimate energy. ${ }^{4}$ More recently, Allen has argued that the relative prices of energy and labour are the key reason behind the British origins of industrialization, as they induced labour-saving technological innovation. ${ }^{5}$ Not only the origins but also the diffusion of industrialization can be traced by flows of energy: the expansion of the 'British model' of energy consumption was, according to Warde, a necessary condition for modern economic growth in Europe. ${ }^{6}$ Going beyond the West, Pomeranz emphasized luck in coal location as a major reason behind Britain's industrial precocity vis-à-vis the Chinese Yangzi delta, while Malanima argued that the specific ecological conditions of early modern Europe produced agrarian systems with an earlier and stronger need for fossil fuels than in China. ${ }^{7}$

Of course, many other scholars reject the idea that energy endowments in general, and coal reserves in particular, were one of the keys to the British origins of the Industrial Revolution, and of the wider process of modern economic growth in the West. McCloskey argued that, just like any other input, coal can be (and indeed was) moved and imported, so not having domestic energy resources should not have been an impediment for industrialization or modern economic growth. ${ }^{8}$ In the same vein, when criticizing Allen's induced innovation hypothesis, Mokyr claimed that cheap coal was a consequence of the Industrial Revolution, rather than one of its causes. ${ }^{9}$ In a recent cliometric effort to quantify the part played by coal in British industrialization, Clark and Jacks explored several counterfactual scenarios, and suggested that, if Britain had not had coal but had had access to it from nearby suppliers (in a world where the Netherlands or Ireland were coal-rich instead of Britain), the course of the Industrial Revolution would not have changed. Yet they admit the counterfactual speculation becomes much more difficult to pursue if we imagine that it was the whole of Europe which lacked coal, though they still argue against Wrigley's and Pomeranz's positions. ${ }^{10}$

\footnotetext{
${ }^{4}$ Carlo M. Cipolla, The economic history of world population, Harmondsworth: Penguin, 1970; E. A. Wrigley, Continuity, chance and change: the character of the Industrial Revolution in England, Cambridge: Cambridge University Press, 1988, pp. 17-33; E. A. Wrigley, Poverty, progress, and population, Cambridge: Cambridge University Press, 2004 , pp. 44-67.

${ }^{5}$ Robert C. Allen, The British Industrial Revolution in global perspective, Cambridge: Cambridge University Press, 2009, pp. 135-56.

${ }^{6}$ Paul Warde, 'A modern energy regime', in Astrid Kander, Paolo Malanima, and Paul Warde, Power to the people: energy in Europe over the last five centuries, Princeton, NJ: Princeton University Press, 2013, pp. 131-58.

${ }^{7}$ Kenneth Pomeranz, The Great Divergence: China, Europe, and the making of the modern world economy, Princeton, NJ: Princeton University Press, 2000, p. 62; Paolo Malanima, 'Energy crisis and growth 1650-1850: the European deviation in a comparative perspective', Journal of Global History, 1, 1, 2006, pp. 101-21.

${ }^{8}$ Deirdre N. McCloskey, Bourgeois dignity: why economics can't explain the modern world, Chicago, IL: University of Chicago Press, 2010, pp. 186-92.

${ }^{9}$ Joel Mokyr, The enlightened economy: an economic history of Britain, 1700-1850, New Haven, CT, and London: Yale University Press, 2009, pp. 268-70.

${ }^{10}$ Gregory Clark and David Jacks, 'Coal and the Industrial Revolution, 1700-1869', European Review of Economic History, $11,1,2007$, pp. 39-72.
} 
This debate has sparked a series of country studies, exploring the impact of coal (that is, of the relative ease or difficulty - translated into economic cost - of its provision) in different geographical and historical contexts, but mostly within Europe. ${ }^{11}$ The comparison pursued here reaffirms the usefulness of an energy perspective, and the importance of King Coal for modern economic growth beyond his traditional realm of industrialization in the West, but it also offers an olive branch to the critics. Sheer availability of coal reserves does not by itself explain anything, and indeed coal could be (and was) imported into Uruguay, where a process of modern economic growth without domestic fossil fuels did take place at about the same time as in coal-plentiful New Zealand.

Yet, as the differences between Clark and Jack's two counterfactual scenarios suggest for the British case, I argue that this story cannot be told without thinking about conditions of access to coal. Energy prices, which reflected those conditions, still matter for explaining why New Zealand consumed about four times as much coal as Uruguay per unit of output, and stayed about 50\% richer in this period. The argument here is not that a lack of domestic energy resources necessarily hinders development, but that energy dependency, if and when it translates into high energy price levels and volatility, is a significant comparative drawback, particularly during times of fast and energy-intensive technological change. Despite the fact that there was no industrial revolution in New Zealand or in Uruguay, access to modern energy at low and stable prices made a difference: from the First Globalization onwards, rural capitalism in the peripheries also needed modern energy.

\section{Tracing the comparison}

By 1913, the average New Zealander or Uruguayan was $60 \%$ richer than his or her grandparents (far more so if those grandparents were, as was fairly likely, working-class Europeans), had more social and labour rights, and fewer children. ${ }^{12}$ The landscape where she or he lived - for the first time in the history of these countries probably a city - had significantly changed, and that change was mainly due to human intervention. Ecological transformation was a result of the increased scale and scope of livestock production encouraged by foreign demand, but led by local entrepreneurs, as ruminants continued to dominate over ploughs. Even as cities and ports grew larger, which had crucial political consequences, New Zealand and Uruguay remained dependent on the livestock herds in their hinterlands to provide dynamic export commodities, which kept their balance of payments in equilibrium.

\footnotetext{
${ }^{11}$ Good examples are: for Italy, Carlo Bardini, 'Without coal in the age of steam: a factor-endowment explanation of the Italian industrial lag before World War I', Journal of Economic History, 57, 3, 1997, pp. 633-53; for Spain, Carles Sudrià, 'Energy as a limiting factor to growth', in Pablo Martín Aceña and James Simpson, eds., The economic development of Spain since 1870, Aldershot: Edward Elgar, 1995, pp. 268-309; for Sweden, Astrid Kander and David Stern, 'Economic growth and the transition from traditional to modern energy in Sweden', Energy Economics, 46, 2014, pp. 56-65. A pioneering Latin American case study is Reto Bertoni and Carolina Román, 'Auge y ocaso del carbón mineral en Uruguay: un análisis histórico desde fines del siglo XIX hasta la actualidad', Revista de Historia Económica/Journal of Iberian and Latin American Economic History, 31, 3, 2013, pp. 459-97.

${ }^{12}$ For per capita GDP estimates, see Jutta Bolt, Robert Inklaar, Herman de Jong, and Jan Luiten van Zanden, 'Rebasing "Maddison": new income comparisons and the shape of long-run economic development', Maddison Project Working Paper 10, 2018, https:/www.rug.nl/ggdc/html_publications/memorandum/gd174.pdf (consulted 27 November 2019). For family structure and labour and social rights in New Zealand, see Erik Olssen, 'Towards a new society', in Geoffrey Rice, ed., The Oxford history of New Zealand, Auckland: Oxford University Press, 1992, pp. 250-78. On the early demographic transition in Uruguay, see Adela Pellegrino, Wanda Cabella, Mariana Paredes, Raquel Pollero, and Carmen Varela, 'De una transición a otra: la dinámica demográfica del Uruguay en el siglo XX', in Benjamín Nahum, ed., El Uruguay del siglo XX: la sociedad, Montevideo: Ediciones Banda Oriental, 2008, pp. 11-44; and on labour rights, see Magdalena Bertino, Reto Bertoni, and Héctor Tajam, Historia económica del Uruguay, tomo III: la economía del batllismo y los años veinte, Montevideo: Fin de Siglo, 2005, pp. 11-27.
} 
Among the world's land-abundant economies, persistent pastoral specialization in New Zealand and Uruguay stands as an exception to the nineteenth- and early twentieth-century global pattern of grassland conversion, during which vast grazing areas were turned to cropland. This happened across the great plains of the US, the Canadian prairies, the Russian and Ukrainian steppe, the savannas of West Africa, and, indeed, in Uruguay's and New Zealand's larger neighbours, in the Argentine humid pampas and the temperate plains of south-eastern Australia. ${ }^{13}$ In contrast, grass remained the dominant plant cover across Uruguay's gently undulating landscape throughout the First Globalization and beyond, occupying more than $80 \%$ of productive lands. In New Zealand, grass cover doubled in size, expanding from the South Island to dominate the North Island as well, in a process of environmental transformation which followed the violent appropriation of Māori lands in the 1860s. ${ }^{14}$

Arising from their demographic, environmental, and economic similarities (Table 1), a broadbrush modern history of both countries can be told as variations on a common theme. Extremely peripheral from the perspective of the economic and political cores of the West, New Zealand and Uruguay were marginal regions in the world economy of the early nineteenth century. Though born from two different waves of European imperial expansion, a century apart, and under the aegis of two different metropoles, both countries were sparsely populated prior to European arrival, and were by no means the crowning jewel of their empires. Transport costs were so high that their production was not competitive in European markets, with the only exception being goods produced at extremely low cost (Uruguayan cattle hides), or those which had a remarkably high value-to-weight ratio (New Zealand gold). ${ }^{15}$

Distance was challenged by coal, steam, and human ingenuity in the form of the late nineteenth-century transportation revolution. Benefiting from abundant agricultural land in relation to population, natural sea harbours, and favourable climates, in the two generations before the First World War, New Zealand and Uruguay became small but highly specialized livestock export economies that could feed many times their own populations, as the Londoners who developed a taste for Canterbury lamb or Fray Bentos beef extract could attest. Despite fast-growing meat production, wool remained the top export commodity for both countries, which were home to similarly large sheep herds. Crucially for New Zealand, its crossbreeds produced its top two staples (wool and mutton), whereas Uruguay needed two species to produce its top commodities (wool and beef), which created an upward pressure on stocking densities, with long-term environmental consequences that should be the subject of another article. ${ }^{16}$

Both countries remained sparsely populated by global standards, and were soon characterized by slow rates of natural population increase, resulting from a very early (by southern hemisphere standards) demographic transition to lower birth and death rates. ${ }^{17}$ European immigration (with a longer history in Uruguay than in New Zealand) was a major source of population growth, and was actively encouraged by both governments. Uruguay's government created an increasingly large institutional framework for the reception of migrants from the 1880s, with the Migration

\footnotetext{
${ }^{13}$ John R. McNeill, 'Energy, population, and environmental change since 1750: entering the Anthropocene', in John R. McNeill and Kenneth Pomeranz, eds., The Cambridge world history, volume VII: production, destruction, and connection, 1750-present, Cambridge: Cambridge University Press, 2015, pp. 72-3.

${ }^{14}$ For a long-term comparative study of the uses of land in livestock production in both economies, see Jorge Álvarez, 'Technological change and productivity growth in the agrarian systems of New Zealand and Uruguay (1870-2010)', in Vicente Pinilla and Henry Willebald, eds., Agricultural development in the world periphery, Basingstoke: Palgrave Macmillan, 2018, pp. 467-92. For an environmental perspective, see Robert Peden, 'Pastoralism and the transformation of the open grasslands', in Tom Brooking and Eric Pawson, eds., Seeds of empire: the environmental transformation of New Zealand, London: I. B. Tauris, 2011, pp. 73-93.

${ }^{15}$ Álvarez and Bértola, 'So similar', p. 497.

${ }^{16}$ I thank one of the Journal's anonymous reviewers for inviting me to consider this point more carefully.

${ }^{17}$ Population in 1870 was 291,000 in New Zealand and 420,000 in Uruguay; by 1913 it had risen to 1,146,000 and 1,169,000 respectively. Phil Briggs, Looking at the numbers: a view of New Zealand's economic history, Wellington: New Zealand Institute of Economic Research, 2007, p. 27; Programa de Población, Base de datos sociodemográficos, Montevideo: FCS-UdelaR, 2014.
} 
Table 1. New Zealand and Uruguay: geography, population, and economy, c.1910

\begin{tabular}{|c|c|c|}
\hline & New Zealand & Uruguay \\
\hline Latitude & $40^{\circ}-45^{\circ}$ south & $30^{\circ}-35^{\circ}$ south \\
\hline Climate zone (Köpen-Geiger) & $\begin{array}{c}\text { Cfb (warm temperate } \\
\text { oceanic) }\end{array}$ & $\begin{array}{c}\text { Cfa (warm temperate } \\
\text { subtropical) }\end{array}$ \\
\hline Avg annual temperature in largest city $\left({ }^{\circ} \mathrm{C}\right)$ & 15.2 & 17.9 \\
\hline Avg yearly rainfall in largest city $(\mathrm{mm})$ & 997 & 1,093 \\
\hline Pastures and grasslands (million hectares) & 12.6 & 15.3 \\
\hline Population (millions) & 1.05 & 1.12 \\
\hline Urbanization (\% of people living in towns) ${ }^{a}$ & 47.8 & c. $46^{\mathrm{b}}$ \\
\hline Immigration (\% of population foreign-born) ${ }^{c}$ & 28.8 & 17.4 \\
\hline Real GDP per capita index (core economies $=100)^{\mathrm{d}}$ & 113 & 69 \\
\hline Export coefficient (X/GDP) & 0.25 & 0.23 \\
\hline Key commodities (\% of export value, $1900-13$ ) & $\begin{array}{c}\text { wool }(34 \%) \\
\text { meat }(19 \%) \\
\text { dairy }(12 \%)\end{array}$ & $\begin{array}{c}\text { wool }(38 \%) \\
\text { meat }(19 \%) \\
\text { hides }(17 \%)\end{array}$ \\
\hline Cattle (millions) & 2.1 & 8.2 \\
\hline Sheep (millions) & 23.9 & 26.3 \\
\hline
\end{tabular}

a follow the thresholds used by primary sources and demographic historians to define towns for both countries, which unfortunately are not the same: 1,000 inhabitants for New Zealand, 2,000 for Uruguay.

${ }^{\mathrm{b}}$ The first official census reporting urbanization rates for Uruguay is from 1963; demographers estimate, on the basis of district returns, that between $40.5 \%$ and $44.7 \%$ of the population lived in towns with more than 2,000 inhabitants by 1908 .

'Foreign-born' here means anyone who was not born in New Zealand or Uruguay respectively (i.e. considering British or Commonwealth subjects born overseas as foreigners (unlike New Zealand censuses)).

${ }^{d} 100=$ simple average of real GDP per capita of the four core Western economies (France, Germany, the UK, and the US). Sources: climate: Markus Kottek et al., 'World map of the Köppen-Geiger climate classification updated', Meteorologische Zeitschrift, 15, 3, 2006, pp. 259-63. Temperature and rainfall in Auckland and Montevideo: New Zealand official year-book, 1913, Wellington, 1913; Anuario estadístico de la República Oriental del Uruguay, 1913-14, Montevideo : Dirección General de Estadística, 1915. Population: Gerard T. Bloomfield, New Zealand: a handbook of historical statistics, Boston, MA: Hall, 1984; Adela Pellegrino, La población de Uruguay, Montevideo: UNFPA, 2010. Urbanization: Campbell Gibson, 'Urbanization in New Zealand: a comparative analysis', Demography, 10, 1, 1973, pp. 71-84; Juan Rial and Jaime Klaczko, Uruguay: el país urbano, Montevideo: Banda Oriental, 1981. GDP: Bolt et al., 'Rebasing "Maddison"'. Exports: Phil Briggs, Looking at the numbers: a view of New Zealand's economic history, Wellington: New Zealand Institute of Economic Research, 2007; Nicolás Bonino-Gayoso, Antonio Tena-Junguito, and Henry Willebald, 'Uruguay and the First Globalization: on the accuracy of export performance, 1870-1913', Revista de Historia Económica, 33, 2, 2015, pp. 287-320; New Zealand Institute of Economic Research, Data1850, Wellington, 2019, data1850.nz (consulted 27 November 2019). Pastures and livestock: Jorge Álvarez, 'Instituciones, cambio tecnológico y productividad en los sistemas agrarios de Nueva Zelanda y Uruguay: patrones y trayectorias de largo plazo', PhD thesis, Universidad de la República (Uruguay), 2014.

Department publishing pamphlets describing the economic benefits of farming in the country. ${ }^{18}$ Assisted migration schemes to New Zealand since 1870, in which the Agent-General's recruitment agents in London played a major part, were highly successful. Nevertheless, as Hawke persuasively argued, the assisted passage schemes would not have been as popular without the underlying economic comparison between the prospects of farming in England and in New Zealand. ${ }^{19}$

The highly productive cattle farms and sheep stations that attracted migrants also fuelled the growth of cities, as most of the employment in livestock production was in its downstream industries, which were spatially concentrated in towns. This contributed to urbanization rates in both countries becoming some of the highest in the southern hemisphere. ${ }^{20}$ The strengthening of statehood, and the primacy of urban politics, were both conditions and results of the process of economic growth and integration to the world economy: provision of public goods was increasingly necessary, and the rapidly growing population and output per capita meant that the state had more trade to tax, more services to charge, and more resources to draw upon.

\footnotetext{
${ }^{18}$ See Carlos Zubillaga, La utopía cosmopolita: tres perspectivas históricas de la inmigración masiva en Uruguay, Montevideo: FHCE, 1998, pp. 61-98; María del Pilar Cagiao Vila, 'La inmigración gallega en Uruguay (1870-1936)', Anuario Americanista Europeo, 3, 2005, pp. 93-112.

${ }^{19}$ G. R. Hawke, The making of New Zealand: an economic history, Cambridge: Cambridge University Press, 1985, pp. 10-15.

${ }^{20}$ The relationship between extensive livestock production and urbanization was first explored systematically for Uruguay in Susana Prates, Ganadería extensiva y población, Montevideo: CIESU, 1976.
} 
Changes in material life connected with political, cultural, and intellectual forces in both countries to produce reform agendas, which the contemporary press described as 'state socialism' and 'Jacobinism'. ${ }^{21}$ Mass immigration, comparatively high incomes, and rising state expenditure coalesced in these small-scale settings to produce progressive politics and active economic and social policies. In an increasingly global world, where telegraphs allowed information to travel fast enough to make local politics internationally known, both countries rapidly earned a reputation for being 'social laboratories'. ${ }^{22}$ The parliaments in Wellington and Montevideo passed legislation that was considered extremely bold, even in affluent Western democracies, such as women's suffrage in New Zealand, or women's unilateral and unconditional right to divorce in Uruguay. Governments expanded welfare provision, with progressively broad pension schemes and increased funding for public health and education. They also contemplated a larger role for the state in the economy, with the government developing infrastructure, and public companies providing key services, decisively reshaping the political landscape of both countries for decades to come. $^{23}$

Despite all these similarities, a significant income gap between New Zealand and Uruguay has remained unbridged for the last century and a half. If New Zealand was 'born rich' thanks to the mid-nineteenth-century gold rush, it managed to remain about $50 \%$ richer than Uruguay thereafter ${ }^{24}$ Explaining why, how, and when that gap became consolidated has motivated a comparative history literature since the 1970s, which has largely placed the interpretative emphasis on institutional trajectories as the forces behind the persistent gap. ${ }^{25}$

The two most recent book-length works devoted to the comparison reflect this consensus. Jorge Álvarez developed a systematic comparison of the divergent institutional trajectories of the agrarian systems of New Zealand and Uruguay, which in his view decisively affected the aggregate performance of both economies, allowing New Zealand to avoid the pattern of high inequality and low returns per acre that came to characterize the Uruguayan landholding system. ${ }^{26}$ Contrary to the 'path dependence' literature, Álvarez considered institutional evolution to be a fundamentally non-linear process, which, in the case of landownership structures in Uruguay and New Zealand, cannot be traced back to colonial policies, or explained by their legal legacies. ${ }^{27}$ Andre Schlueter also produced an institutionalist analysis, but one much closer to the mainstream versions of new institutional economics, drawing in particular from the theoretical framework of

\footnotetext{
${ }^{21}$ 'Lord Onslow on "state socialism in New Zealand", New Zealand Herald, 26 December 1893; José Enrique Rodó, 'Liberalismo y jacobinismo', La Razón, 5 July 1906.

${ }^{22}$ Percy A. Harris, New Zealand and its politics, London: Headley Bros., 1909, p. 9; Simon Gabriel Hanson, Utopia in Uruguay: chapters in the economic history of Uruguay, New York: Oxford University Press, 1938, p. 5.

${ }^{23} \mathrm{Good}$ historical overviews of these policies and their outcomes can be found in Gerardo Caetano, La república batllista, Montevideo: Ediciones de la Banda Oriental, 2011; Len Richardson, 'Parties and political change', in Rice, Oxford history of New Zealand, pp. 201-29.

${ }^{24}$ Similarly, Díaz Alejandro argued that Australia had been 'born rich’ in comparison with Argentina. Carlos Federico Díaz Alejandro, 'No less than one hundred years of Argentine economic history plus some comparisons', in Andrés Velasco, ed., Trade, development and the world economy: selected essays of Carlos Díaz Alejandro, Oxford: Basil Blackwell, 1988, pp. $230-60$.

${ }^{25}$ Early examples are John Kirby, 'On the viability of small countries: Uruguay and New Zealand compared', Journal of Interamerican Studies and World Affairs, 17, 3, 1975, pp. 259-80; José Pedro Barrán and Benjamín Nahum, Agricultura, crédito y transporte bajo Batlle, 1905-1914, Montevideo: Ediciones de la Banda Oriental, 1978, pp. 191-9. Some of the classic arguments are restated, reviewed, and revised in the contributions to Jorge Álvarez, Luis Bértola, and Gabriel Porcile, eds., Primos ricos y empobrecidos: crecimiento, distribución del ingreso e instituciones en Australia-Nueva Zelanda vs ArgentinaUruguay, Montevideo: Fin de Siglo, 2007.

${ }^{26}$ Jorge Álvarez, Instituciones, cambio tecnológico y distribución del ingreso: una comparación del desempeño económico de Nueva Zelanda y Uruguay (1870-1940), Montevideo: Universidad de la República, 2013.

${ }^{27}$ Jorge Álvarez, 'Instituciones, cambio tecnológico y productividad en los sistemas agrarios de Nueva Zelanda y Uruguay: patrones y trayectorias de largo plazo', PhD thesis, Universidad de la República (Uruguay), 2014, pp. 259-60. For a survey and a critique of the economic and social science literature devoted to studying path-dependent processes in historical data sets containing 'natural experiments', see Jan de Vries, 'Changing the narrative: the new history that was and is to come', Journal of Interdisciplinary History, 48, 3, 2018, pp. 313-34.
} 
North, Wallis, and Weingast. ${ }^{28}$ Schlueter characterizes New Zealand as an 'open access order', and Uruguay as a 'limited access order', and argues for a positive relationship between relative prosperity and contract rights enforcement, although he finds that New Zealand's 'open access' conditions were more recent and less effective for rapid growth than previously assumed. Importantly for the argument pursued here, he rejects differences in endowments as the main explanatory factor of the different fortunes of New Zealand and Uruguay, although he does admit that technology played a role 'potentially' more important than a framework such as that of North, Wallis, and Weingast would acknowledge. ${ }^{29}$

This article does not deny the relevance of institutions in general (or colonial legacies in particular) in economic history, but it does try to balance an emphasis that, when excessive, can prove misleading, as Schlueter himself acknowledges. ${ }^{30}$ Spanish and British colonizers, and the institutions that they brought with them, certainly shaped Uruguay and New Zealand, but the modern history of these countries should not be told simply as a tale of two small neo-Europes, but also as one of very southern and non-European environments. ${ }^{31}$

In particular, conditions of access to coal, which translated into significant differences in energy prices, contributed to keeping the income gap between the two countries open during one of their periods of fastest growth, the commodity-led boom before the First World War. In emphasizing the material realities of agro-industrial production, and the specificities of the natural resources on which New Zealand and Uruguayan economic development was built, this article attempts to contribute to the reassessment of the part played by the environment, which has been taking place in the comparative literature. ${ }^{32}$ Álvarez, Bértola, and Porcile pointed to the development of a large mining sector in New Zealand and Australia, as a key to understanding the origins of their greater prosperity relative to Uruguay and Argentina. ${ }^{33}$ Furthermore, and closely related to the argument pursued here, Bertoni and Willebald showed that the similarities in natural endowments between New Zealand and Uruguay should be greatly qualified in terms of energy resources, and explored the impact of this difference in the long-term development of the two economies. ${ }^{34}$ Their study therefore pioneered a more systematic analysis of the part played by energy in the specialist literature. In this article, I try to move the discussion forward by tracing the effects of these two different energy economies on the choices of techniques and material processes behind meat production for export in New Zealand and Uruguay before 1914.

This analysis should be framed as part of the larger history of food production in settler economies during the First Globalization. In particular, Jeremy Adelman's comparative study of the mechanization of the wheatlands of Argentina and Canada offers valuable insights for understanding the complex factors surrounding the choice of techniques in such contexts. ${ }^{35}$ In these settings characterized by land abundance, labour scarcity, and a comparative advantage in export agriculture, Adelman found that the choice between alternative methods of production was not merely the result of comparing abstract production functions, but that it was framed by its broader social and economic context. In particular, and relevant to our comparison, producers

\footnotetext{
${ }^{28}$ Douglass C. North, John Joseph Wallis, and Barry R. Weingast, Violence and social orders: a conceptual framework for interpreting recorded human history, Cambridge: Cambridge University Press, 2009.

${ }^{29}$ Andre Schlueter, Institutions and small settler economies: a comparative study of New Zealand and Uruguay, 1870-2008, Basingstoke: Palgrave Macmillan, 2014, pp. 201-9.

${ }^{30}$ Explanations solely focusing on inherited culture and irrevocable path dependency ... would hardly capture the early rise and later (relative) decline of New Zealand and Uruguay' (ibid., p. 209).

${ }^{31}$ Alfred W. Crosby, Ecological imperialism: the biological expansion of Europe, 900-1900, Cambridge: Cambridge University Press, 2015, p. 222.

${ }^{32}$ Álvarez, 'Technological change'; Brooking and Pawson, Seeds of empire.

${ }^{33}$ Álvarez, Bértola, and Porcile, Primos ricos, p. 12.

${ }^{34}$ Reto Bertoni and Henry Willebald, 'Do natural energy endowments matter? New Zealand and Uruguay in a comparative perspective, 1870-1940’, Australian Economic History Review, 56, 1, 2016, pp. 70-99.

${ }^{35}$ Jeremy Adelman, 'The social bases of technical change: mechanization of the wheatlands of Argentina and Canada, 1890 to 1914', Comparative Studies in Society and History, 34, 2, 1992, pp. 271-300.
} 
were biased in favour of known techniques, which, in the case of meat production for external markets, had a much longer history in Uruguay than in New Zealand. The interrelatedness of technology also meant that previous investments affected the decision to buy new machines, which in our case suggests that, if a factory was already set up to produce meat extract, the opportunity cost of overhauling the whole operation to produce frozen meat became much higher.

Finally, the politics and economics of empire are crucial to our two stories, and allow us to place them in the broader comparative economic history of their larger neighbours, Australia and Argentina. The First Globalization was both a 'golden era of resource-based development' and a time of 'imperialism of free trade'. ${ }^{36}$ Given that Australasia and the River Plate were prime examples of resource-based developing economies, and sat at opposite ends of the formal/informal empire continuum, the comparison should also move us to reflect on the interplay between empire and resource-intensive capitalist development in the periphery. ${ }^{37}$ For present purposes, it is important to consider whether Australia and New Zealand benefited from British direct investment and associated technology transfer in a way that Argentina and Uruguay did not, and whether that can contribute to explaining the persistent income gap between these countries.

The economic historiography on empire suggests that formal imperialism worked quite well with settler capitalism. Indeed, British imperial rule resulted in greater economic benefit for the 'neo-Britains' of Australia, Canada, and New Zealand than for the metropolis, which would explain the lateness of their final political independence. ${ }^{38}$ Thus, Australasia received very large inflows of British investment during this period. New Zealand alone received $£ 84$ million by 1913, which was more than any other colony in per capita terms. ${ }^{39}$ However, the River Plate's position within Britain's informal empire meant that not being a dominion was not an obstacle for receiving capital and technology transfer. ${ }^{40}$ By 1913 , British investment in Uruguay alone reached $£ 47$ million, including railways, gas works, factories, and other technology-intensive sectors. This exceeded Britain's investments in many of her colonies at the time. ${ }^{41}$ And yet, as Denoon argued in his seminal work, imperial preference may have given New Zealand and Australia an advantage over Uruguay and Argentina, and it clearly did so in terms of market access after the Ottawa Conference in $1931{ }^{42} \mathrm{I}$ would argue, however, that during the First Globalization the closeness of economic ties with Britain was more a similarity than a difference between these southern settler economies.

\section{Coal prices in New Zealand and Uruguay}

The export era centred on pastoral commodities was fossil-fuelled in both countries, but to a much larger extent in New Zealand, whose coal intensity (measured as coal consumed in physical terms

\footnotetext{
${ }^{36}$ Edward Barbier, Scarcity and frontiers: how economies have developed through natural resource exploitation, Cambridge: Cambridge University Press, 2011, pp. 368-462. John Gallagher and Ronald Robinson, 'The imperialism of free trade', Economic History Review, 6, 1, 1953, pp. 1-15.

${ }^{37}$ Landmark studies on empire in the cases of Uruguay and New Zealand are Peter Winn, 'British informal empire in Uruguay in the nineteenth century', Past \& Present, 73, 1976, pp. 100-26; W. David McIntyre, 'Imperialism and nationalism', in Rice, Oxford history of New Zealand, pp. 337-50.

${ }^{38}$ Gareth Austin, 'Capitalism and the colonies', in Larry Neal and Jeffrey G. Williamson, eds., The Cambridge history of capitalism, volume II: the spread of capitalism: from 1848 to the present, Cambridge: Cambridge University Press, 2014, p. 312; Anthony G. Hopkins, 'Rethinking decolonization', Past \& Present, 200, 2008, pp. 211-47.

${ }^{39}$ William N. Goetzmann and Andrey D. Ukhov, 'British investment overseas 1870-1913: a modern portfolio theory approach', Review of Finance, 10, 2, 2006, p. 270.

${ }^{40}$ Winn, 'British informal empire', pp. 109-16; A. G. Hopkins, 'Informal empire in Argentina: an alternative view', Journal of Latin American Studies, 26, 2, 1994, pp. 469-84; D. C. M. Platt, Latin America and British trade, 1806-1914, London: Adam and Charles Black, 1972, pp. 287-8.

${ }^{41}$ Irving Stone, 'British direct and portfolio investment in Latin America before 1914', Journal of Economic History, 37, 3, 1977, p. 695; Lance E. Davis and Robert A. Huttenback. Mammon and the pursuit of Empire: the political economy of British imperialism, 1860-1912. Cambridge: Cambridge University Press, 1986.

${ }^{42}$ Denoon, Settler capitalism. See also John Singleton, 'New Zealand, Britain and the survival of the Ottawa Agreement, 1945-77', Australian Journal of Politics and History, 43, 2, 1997, pp. 168-82.
} 


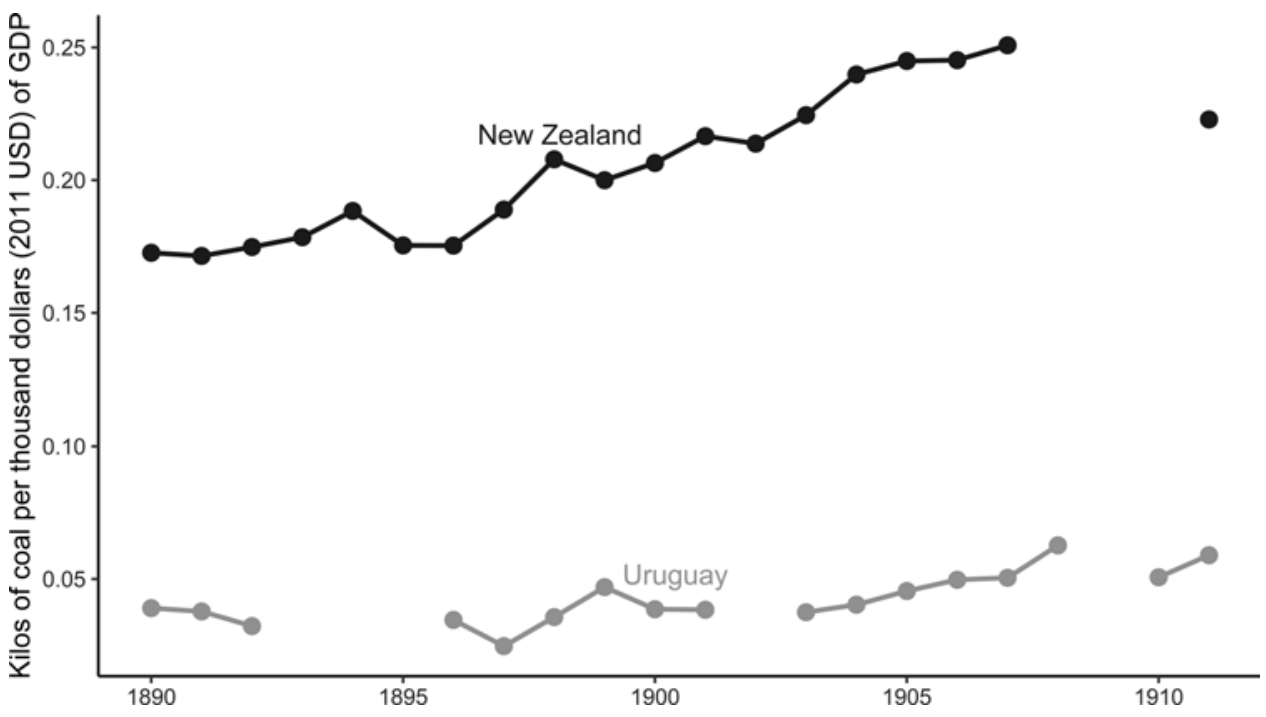

Figure 1. Coal intensity in New Zealand and Uruguay, 1890-1911 (kilos of coal per US\$1,000, in 2011 US\$). Apparent consumption of coal is estimated as domestic production + imports - exports. Sources: New Zealand coal figures, New Zealand official year-book, 1891-1912; British Parliamentary Papers, Coal tables, 1912 and 1924. Uruguay coal figures: Anuarios estadísticos, 1891-1912. GDP from Bolt et al., 'Rebasing "Maddison"'.

divided by GDP in constant prices) was about four times higher than Uruguay's, where coal imports just about managed to keep pace with economic growth before 1914 (figure 1). The transition from animal draft power and firewood to coal and coal-fuelled electricity was, therefore, much more intense in New Zealand, empowering the rapid development of the dairy industry and refrigerated meat-packing. The impact of this early adoption of refrigeration on New Zealand's long-term development has been explored in detail in the local historiography, from the perspective of both economic development and ecological change. ${ }^{43}$ Conditions of market access to coal can help us to understand how New Zealand managed this transition, which was crucial in building its 'protein bridge' to Britain. ${ }^{44}$

New Zealand had substantial coal reserves, and since the mid nineteenth century several coalfields and mines had been opened across the country, taking advantage of the relatively even distribution of the resource in both the North Island and the South Island. ${ }^{45}$ In the three decades before the First World War, at least $85 \%$ of the New Zealand demand for coal was consistently supplied by domestic production, the rest being imported from nearby Australia. ${ }^{46}$ In the event of an unexpected increase in demand, the mines in New South Wales could be counted upon to provide even more cheap coal with low transportation costs. Uruguay lacks coal completely, and in this period the demand was supplied almost entirely (92\% on average between 1890 and 1911) by imports from distant Britain. ${ }^{47}$

\footnotetext{
${ }^{43}$ See, respectively, Hawke, Making of New Zealand, pp. 84-102; Jim McAloon, 'Mobilising capital and trade', in Brooking and Pawson, Seeds of empire, pp. 105-15.

${ }^{44}$ James Belich, Paradise reforged: a history of the New Zealanders from the 1880s to the year 2000, Auckland: Allen Lane, 2001, p. 68.

${ }^{45}$ John Bell Condliffe, New Zealand in the making: a survey of economic and social development, London: Allen \& Unwin, 1930, p. 164; Muriel F. Lloyd Prichard, An economic history of New Zealand to 1939, Auckland: Collins, 1970 , p. 200.

${ }^{46}$ As reported by Statistics New Zealand, New Zealand official year-book, and the British Parliamentary Papers' Coal tables, each issued annually.

${ }^{47}$ Dirección General de Estadística, Anuario estadístico de la República Oriental del Uruguay, Montevideo, issued annually.
} 

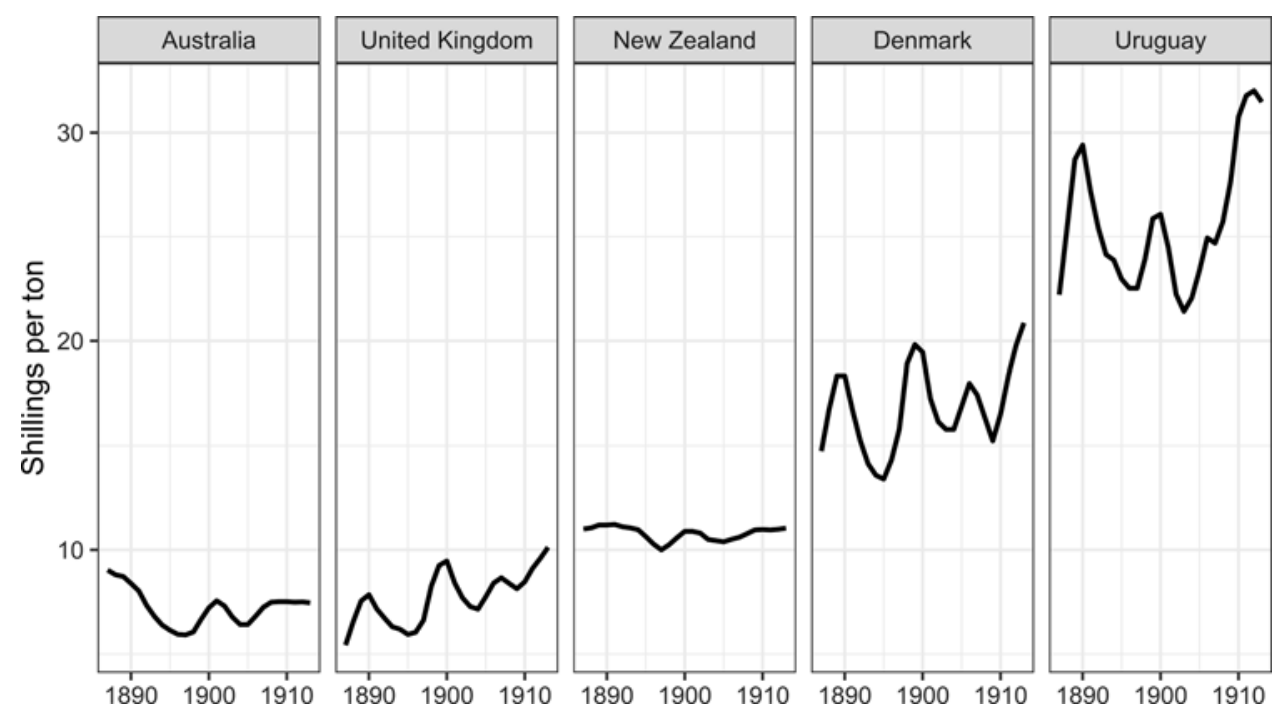

Figure 2. Coal prices: New Zealand and Uruguay in context, 1887-1913, three-year moving averages (shillings per ton). Sources: New Zealand, Australia, and the UK: British Parliamentary Papers, Coal tables, 1894-1924; Denmark: Sofia Teives Henriques and Paul Sharp, 'The Danish agricultural revolution in an energy perspective: a case of development with few domestic energy sources', Economic History Review, 69, 3, 2016, pp. 844-69; Uruguay: author's calculations (see figure 3). Uruguayan and Danish series refer to wholesale price at the ports of Montevideo and Copenhagen. The Australian, British, and New Zealand series refer to price of coal at the pithead.

This stark difference in domestic resources was first systematically analysed by Bertoni and Willebald, who underlined the importance of disaggregating natural resources when comparing settler economies, going beyond an aggregate, homogenous 'natural capital'. ${ }^{48}$ Following that principle, a note on coal varieties is necessary, before considering prices and incentives. Coal is not a homogenous commodity; its energy density (how much heat can be obtained per unit of volume) varies depending on its shares of moisture, trace elements, and incombustible ash: levels vary from as low as $8 \mathrm{MJ} / \mathrm{kg}$ for poor lignites to $36 \mathrm{MJ} / \mathrm{kg}$ for good anthracites, with bituminous coals producing around $25-9 \mathrm{MJ} / \mathrm{kg} .{ }^{49}$ Half of New Zealand's proven reserves $c .1920$ were bituminous or semi-bituminous coal, the other half being brown coals and lignites, while imports from New South Wales were of bituminous coal. This makes average energy-density levels broadly comparable with Uruguayan imports of British 'steam coal', which produced around 20-5 MJ/kg, below that of standard bituminous coal (which represented c.60\% of New Zealand supply) but higher than brown coal and lignites (which accounted for the remaining $40 \%$ of New Zealand supply). ${ }^{50}$ To avoid the complexities resulting from the diverse kinds of coal available in each country at the time, the price series presented in this article refer only to New Zealand's own bituminous and semi-bituminous coal and Uruguay's imports of British 'steam coal', so they can be straightforwardly compared.

Figure 2 shows the evolution of coal prices in New Zealand and Uruguay before 1914. The data for New Zealand refers to the price at the pithead, officially reported for the dominion in the Coal tables presented to the House of Commons between 1894 and 1924. The Uruguayan series has been estimated by adding the different components of the price of coal at Montevideo's harbour and including the custom duties (figure 3 provides details of the components). It is a lower-bound estimate, as it takes the cheapest annual value for the Atlantic transportation of coal from the UK

\footnotetext{
${ }^{48}$ Bertoni and Willebald, 'Do natural energy endowments matter?'

${ }^{49}$ Vaclav Smil, Energy in nature and society: general energetics of complex systems, Cambridge, MA: MIT Press, 2008 , p. 375.

${ }^{50}$ Bertoni and Willebald, 'Do natural energy endowments matter', p. 79; Smil, Energy, p. 375.
} 


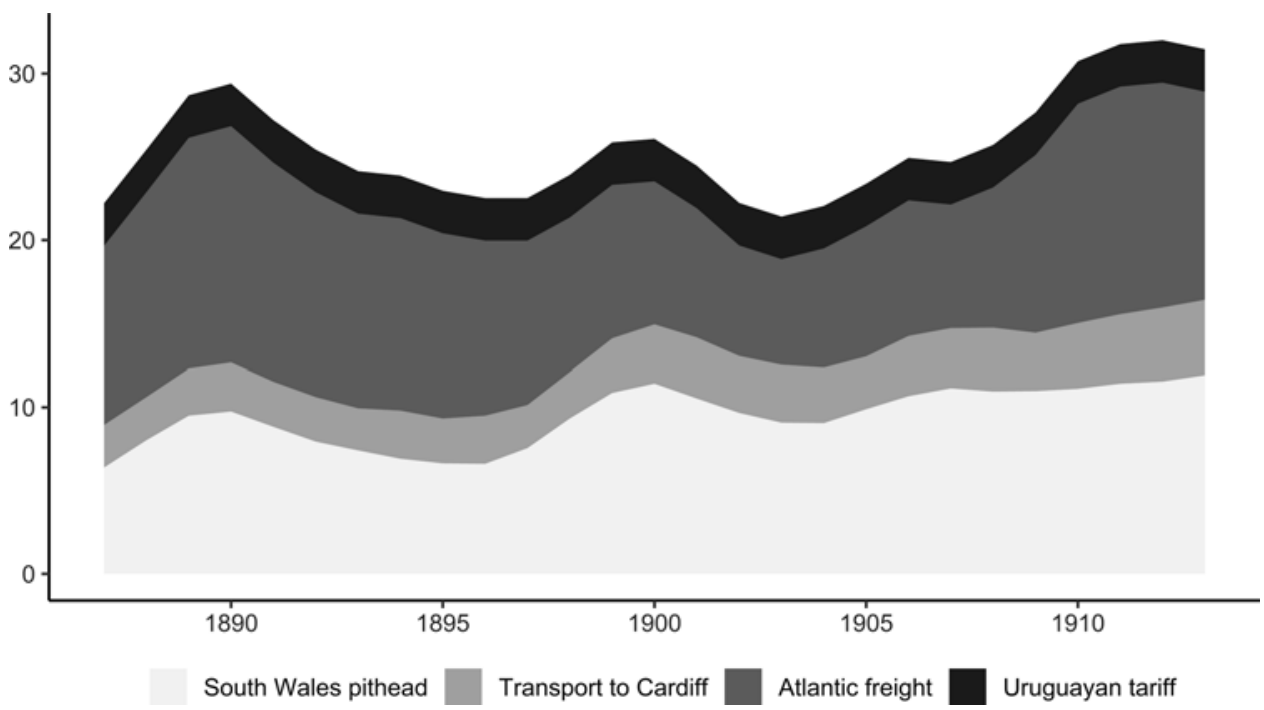

Figure 3. Composition of coal prices at the port of Montevideo, 1887-1913, three-year moving averages (shillings per ton). Sources: pithead price and transport to Cardiff: John Williams, Digest of Welsh historical statistics 1700-1914, vol. 5, Cardiff: Welsh Office, 1985, data now available at http://doi.org/10.5255/UKDA-SN-4097-1 (consulted 9 December 2019); Atlantic freight: E. A. V. Angier, Fifty years of freight, 1869-1919, London: Fairplay, 1920; Uruguayan tariff: Anuarios estadisticos, 1891-1912.

to the River Plate, as registered by the Angier reports for each year. For two years (1910 and 1911), the managers' half-yearly reports and the accounts of the Central Uruguay Railway Company of Monte Video (CUR) provide the price paid by the firm for wholesale coal in Montevideo, which broadly coincides with my estimate for the price at the port. ${ }^{51}$ Hence, even if, owing to middlemen, the wholesale price paid by producers for New Zealand coal was likely somewhat higher than the price reported in the Coal tables, the estimated price at Montevideo's harbour was a likely minimum for the Uruguayan economy as well. The retail prices in both cases were therefore higher than the one presented here, but there is no reason to think the gap between pithead or port price and retail price was notably different in two countries of similar scale such as New Zealand and Uruguay. A British and an Australian series have been added, as they were the main coal exporters to Uruguay and New Zealand respectively. Britain also serves as a lower-bound reference for global coal prices, as the UK was the largest world producer and consumer of coal in this period, and it consistently enjoyed very low prices by any standards. ${ }^{52}$ Finally, a Danish series has been added for reference, as a European case of a small economy which built its progress on energyintensive export agriculture with almost no domestic energy resources. ${ }^{53}$

The price of coal in Montevideo was on average more than two and a half times higher than in New Zealand, and five times more volatile. ${ }^{54}$ These disparities can contribute to explaining why New Zealand producers adopted the most energy-intensive of meat preservation technologies

\footnotetext{
${ }^{51}$ As expected, the price paid by CUR is a bit higher than the price at the port. In 1909-10 CUR paid 26.92 and 30.25 shillings per ton. The estimated price at the port was 23.30 and 28.39 shillings respectively. Central Uruguay Railway Company of Monte Video, Report of the directors to the shareholders with statement of the revenue and capital account, 1910, p. 16.

${ }^{52}$ Warde, 'A modern energy regime', p. 157.

${ }^{53}$ Sofia Teives Henriques and Paul Sharp, 'The Danish agricultural revolution in an energy perspective: a case of development with few domestic energy sources', Economic History Review, 69, 3, 2016, pp. 844-69.

${ }^{54}$ The mean of the New Zealand series is 10.78 shillings and its coefficient of variation is 0.03 , whereas the mean of the Uruguayan series is 23.50 shillings and its coefficient of variation is 0.18 .
} 
(refrigeration) and why Uruguayan production remained anchored in the more traditional beef jerky and in the less capital- and energy-intensive technologies of canning and meat extract. They also need to be explained themselves, as they are not a foregone conclusion of domestic energy endowments.

Coal prices in New Zealand were very low and stable, not only compared to Uruguay, but also by global standards, for three main reasons. First, coal reserves were favourably distributed almost evenly between the North Island and the South Island. ${ }^{55}$ Second, domestic production was, unlike in Britain, almost completely used for domestic consumption. On average, only $11 \%$ of coal production was exported, most of which went to coal bunkers in New Zealand ports, preventing external demand from becoming a destabilizing force in coal price formation. ${ }^{56}$ Third, when necessary, coal imports came from a nearby low-cost producer, Australia. As internal demand expanded consistently throughout the period, domestic production increased accordingly, and the share of imports remained below 15\%. Even if New Zealand was a net coal importer, between its domestic production and the cheap and stable prices offered by neighbouring New South Wales, its energy security was guaranteed. The frequency of round trip maritime transport between the two territories was very consistent throughout the decades, with arrivals and departures coinciding almost exactly. ${ }^{57}$ New Zealand was an important market for the New South Wales coal industry, being the destination on average of $19 \%$ of exports between 1871 and $1914 .{ }^{58}$ It was also important qualitatively. As noted by Bukley, the New South Wales overseas coal trade developed 'as a by-product of the operational needs of the British shipping industry', with the one exception of exports to New Zealand. ${ }^{59}$

High coal prices in Uruguay cannot be simply attributed to dependency on imported energy, or even particularly on British coal. Denmark depended on it as well, but coal prices there were far lower, even if price movements, as in Uruguay, echoed and amplified those in the UK. Of course, Denmark's location was much more favourable in terms of access to energy: north-western Europe is a region extremely rich in coal, whereas South America is one of the poorest in the world. ${ }^{60}$ Yet we would expect the price of coal in Uruguay to start to converge with Denmark's, as the costs of international maritime transportation fell significantly during the period. To understand why that did not happen, we must follow the coal cargo from Cardiff to Montevideo (figure 3).

A major source of volatility, and the main difference with the price levels of other coal importers, was the price of Atlantic freight from Wales to the River Plate. This price reflected the complex dynamics of international transportation routes, in which Uruguay was a price taker, and which were not solely determined by the late nineteenth-century victory of technological change over geographical distance achieved through compound engines, steel hulls, and increasingly powerful boilers. ${ }^{61}$ Expensive and changing freight rates, particularly for British coal being shipped to the River Plate region, caused uncertainty about future coal prices in Montevideo, encouraging pre-emptive rises in price. Thus, the annual peak value of the Cardiff-River Plate freight rate

\footnotetext{
${ }^{55}$ Alan Sherwood and Jock Philips, 'Coal and coal mining: coal resources', in Te Ara: the encyclopedia of New Zealand, http://www.teara.govt.nz/en/coal-and-coal-mining/page-2 (consulted 27 November 2019).

${ }^{56}$ British Parliamentary Papers, Coal tables, 1912, pp. 10-11.

${ }^{57}$ K. H. Bukley, 'The overseas trade in New South Wales coal and the British shipping industry, 1860-1914', Economic Record 36, 75, 1960, p. 398.

${ }^{58}$ Ibid., p. 411.

${ }^{59}$ Ibid., pp. $394-5$.

${ }^{60}$ César Yáñez, María del Mar Rubio, José Jofré, and Albert Carreras, 'El consumo aparente de carbón mineral en América Latina, 1841-2000: una historia de progreso y frustración', Revista de Historia Industrial, 53, 3, 2013, pp. 26-7.

${ }^{61} \mathrm{C}$. Knick Harley, 'Ocean freight rates and productivity, 1740-1913: the primacy of mechanical invention reaffirmed', Journal of Economic History, 48, 4, 1988, pp. 851-76.
} 
reliably predicts the price paid for coal in Montevideo in the following year throughout the period 1897-1913. ${ }^{62}$ It was a case of particularly narrow energy dependence, compounded by an unlucky position in freight dynamics. Cardiff's relevance for the Uruguayan economy can be traced beyond energy statistics: in 1910 it was second only to Buenos Aires as a port of origin for all steamships entering Montevideo. ${ }^{63}$ Finally, Uruguay's tariff policy, while effective for fiscal revenue, did not help its energy economy. ${ }^{64}$ An ad valorem customs duty of $6 \%$ on imported coal, calculated over an extremely inflated fixed administrative value for coal ( 42.5 shillings per ton), was in practice a specific tariff of 2.5 shillings per ton, which did not respond to changes in price, and which made coal even more expensive.

\section{Coal and meat production during the First Globalization}

While (Uruguayan) beef and (New Zealand) mutton were two different meats, their economics were not fundamentally different, for the simple reason that, unlike pork, beef and mutton were both preferred as fresh as possible. Shipping meat halfway across the world, as producers in both countries needed to do in order to reach their European consumers, was a major logistical challenge, and it had far-reaching economic and environmental consequences, as Cronon has shown for the case of contemporary producers in Chicago. They faced a similar problem within their domestic market, as they tried to supply East Coast urban consumers with the by-products of the cattle herds of the Great West. ${ }^{65}$ The diverse techniques for the preservation of beef and mutton available in the late nineteenth century had different factor biases, different energy intensities, and produced commodities that were at varying distances of quality from the superior product (fresh meat). ${ }^{66}$ The closer they resembled it, the faster demand for those products would grow as a response to increases in consumers' incomes.

The traditional method of meat preservation - curing and preserving with salt - was capitaland energy-saving, and resulted in strips of beef jerky (called tasajo or charqui in Latin America). This was Uruguay's key export staple to the plantation economies of Brazil and Cuba for more than a century, but it was not suitable for the increasingly sophisticated international demand during the First Globalization. The main input, besides cattle, in the saladeros (meat-processing plants established from the late eighteenth century onwards) was salt. The infrastructure required, as well as the scale economies, was minimal. ${ }^{67}$

Of the modern technologies, the production of beef extract, patented by Justus von Liebig in the 1860 s, and produced on a large scale for the first time in Fray Bentos on the Uruguay river, was the most land-extensive, as it gave small yields per cow. Cattle flesh was pressed into a pulp with iron rollers, then dropped into hot water, and, after removing some of the fat, pressured into thick gravy, which was then packaged. About $3 \mathrm{~kg}$ of meat were necessary to make $100 \mathrm{~g}$ of extract. ${ }^{68}$

\footnotetext{
${ }^{62} \mathrm{~A}$ Granger causality test suggests that a $£ 1$ increase in cost at time $t-1$ causes a $£ 0.916$ increase in coal price from time $t-1$ to time $\mathrm{t}$ (significant with $\mathrm{p}$-value $=0.013$ ).

${ }^{63}$ Dirección General de Estadística, Anuario estadístico, 1909-10, pp. 336-9.

${ }^{64}$ Custom duties represented well over $60 \%$ of the total fiscal revenue of the Uruguayan state in the period 1870-1904, and about 45\% in 1904-13. Luis Bértola, Ensayos de historia económica: Uruguay y la región en el mundo (1870-1990), Montevideo: Trilce, 2000, p. 179.

${ }^{65}$ William Cronon, Nature's metropolis: Chicago and the Great West, New York: W. W. Norton, 1991, pp. $225-47$.

${ }^{66}$ The technical requirements for producing frozen meat did not vary significantly between beef and mutton. James Troubridge Critchell and Joseph Raymond, A history of the frozen meat trade: an account of the development and present day methods of preparation, transport, and marketing of frozen and chilled meats, London: Constable \& Company, 1912.

${ }^{67} \mathrm{On}$ the transition from saladeros to frigorificos (refrigeration plants) in the Uruguayan livestock industry and its consequences for the wider economy, see Henry Finch, A political economy of Uruguay since 1870, London: Macmillan, 1981, pp. 133-52.

${ }^{68}$ Mark R. Finlay, 'Quackery and cookery: Justus von Liebig's extract of meat and the theory of nutrition in the Victorian age', Bulletin of the History of Medicine, 66, 3, 1992, pp. 404-18.
} 


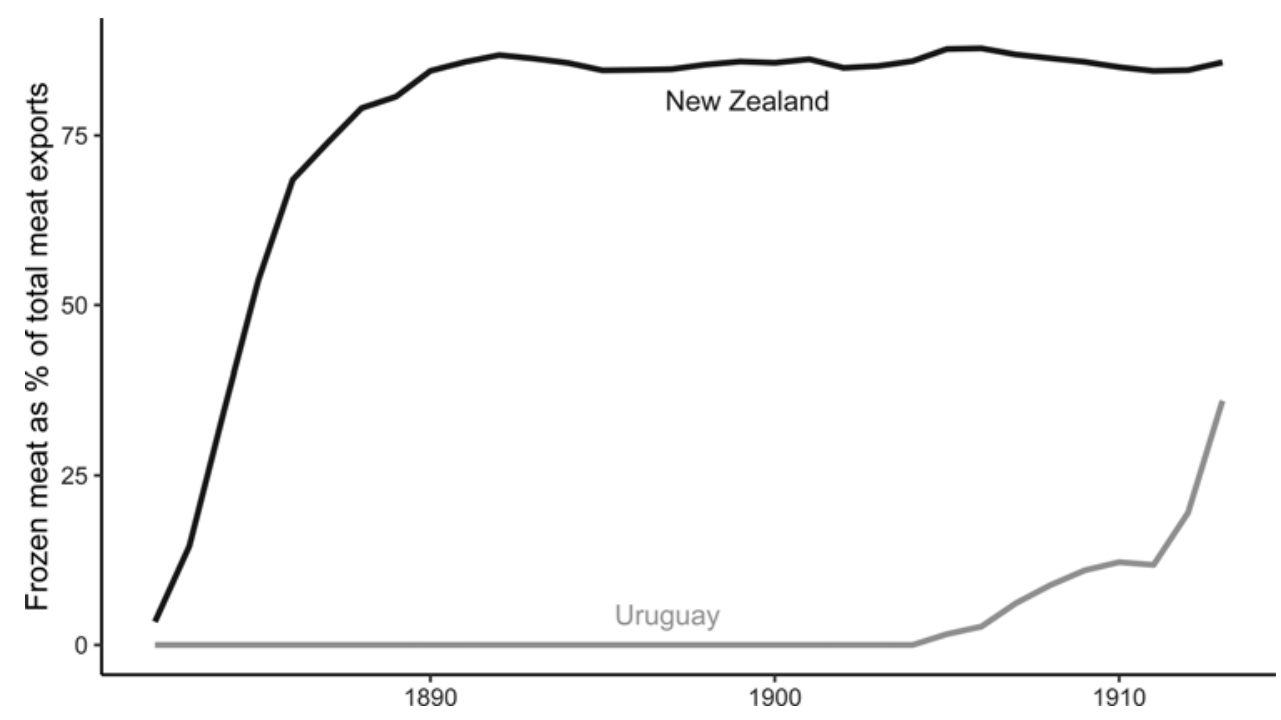

Figure 4. Frozen meat as a share of the total value of exported meat, 1882-1913, three-year moving averages (\%). Sources: New Zealand: Gerard T. Bloomfield, New Zealand: a handbook of historical statistics, Boston, MA: Hall, 1984; Uruguay: Julio Millot and Magdalena Bertino, Historia económica del Uruguay, tomo II: 1860-1910, Montevideo: Fundación de Cultura Universitaria, 1996.

Hailed in Britain as 'the juice and essence of the strong oxen now feeding on the Pampas', the beef extract marketed as OXO became a symbol of Uruguay's global position in the industry. ${ }^{69}$

The boiling down and pressing of cattle meat to produce tinned beef, such as the flagship Fray Bentos corned beef, was a much-improved version of Liebig's method, resulting in a product with higher unit value and income elasticity of demand. Meat was chopped and tightly packed in characteristically rectangular-base cans, which would become a staple of British household larders and military rucksacks. Unlike tasajo, it required significant quantities of energy to boil down the flesh and to hermetically seal the cans, but the produce could then be easily and cheaply stored and transported, as it required no more than a cool dry place.

The most sophisticated method of meat preservation of the late nineteenth century marked a break from all the previous ones. Ammonia-cycle, steam-powered refrigeration had a fundamentally different factor bias, requiring large supplies of coal, not only to freeze the carcasses initially but also to keep them cold for twenty-four hours a day. It also needed sophisticated and expensive transportation, both to a port and across the ocean. In the 1900s, the specialized freight required by frozen meat was on average three times more costly per ton than the transport needed by corned beef, tasajo, and meat extract. ${ }^{70}$ On the upside, chilled and frozen meat had a higher unit value, somewhat compensating for transportation costs, and a much higher income elasticity of demand, only second in the meat market to fresh beef and mutton, which were generally reserved for the upper classes in European cities.

In this technological context, where steam and coal still reigned supreme, the choice of technique differed greatly between New Zealand and Uruguay. Already by $1890,87 \%$ of the total value of New Zealand meat exports were frozen, whereas in Uruguay that figure would remain under 10\% until 1907 (figure 4). New Zealand's rapid transition to refrigerated meat production was a

\footnotetext{
${ }^{69}$ Charles Boner, 'Extract of meat', Popular Science Review, 4, 13, 1865, p. 295. David Edgerton, The shock of the old: technology and global history since 1900, Oxford: Oxford University Press, 2007, pp. 170-1.

${ }^{70}$ Colin Crossley and Robert Greenhill, 'The River Plate beef trade', in D. C. M. Platt, ed., Business imperialism, 1840-1930 : an inquiry based on British experience in Latin America, Oxford: Clarendon Press, 1977, p. 287.
} 
deliberate response to the stiff competition it faced from agrarian producers that were much closer to Britain, and that offered comparatively shorter supply chains. Uruguay was only one of them, and by no means the most challenging. Argentina, Canada, and the United States benefited from scale economies in food production, which New Zealand pastoralism could never attain, while Denmark was ideally situated to supply Britain with farm products.

Geographical location strongly encouraged New Zealand producers to focus on high-unit-value commodities, which required freezing works and refrigerated transportation. Choosing quality over quantity, and stressing product differentiation, was perhaps the only viable export strategy for a small-scale agrarian producer subject to extremely high freight costs. Showing an insider's knowledge of the market, in 1898 New Zealand's Agent-General in London reported to his Minister of Agriculture after his first year in Britain:

Quality, and quality only, enables and will enable our meat to hold its own against its cheaper competitors. The main desiderata, then, are: (1) That the quality should be rigorously preserved; (2) that it should be advertised widely and perseveringly amongst the English middle classes; (3) that efforts should be made by which the wholesale dealers should supply New Zealand meat to retail butchers who will agree to buy no other foreign meat; (4) that all foreign meat should be marked not only as foreign but with the country of its origin. ${ }^{71}$

His advice on marketing was followed by some tenants of the Smithfield Market, who asked the superintendent to have a sign reading 'New Zealand meat producing companies' on their shops. ${ }^{72}$

In contrast, the lateness with which freezing works were established in Uruguay - the country with the highest ratio of cattle to people in the world then and now ${ }^{73}$ - cannot be explained away simply by a lack of capitalist ethos, nor by government policies (or lack thereof) stifling adoption of innovations. Indeed, Charles Tellier (the French père $d u$ froid) was funded by Uruguayan producers to develop refrigerated transport, and the first port at which the Frigorifique called south of the Equator was Montevideo, five years before the Dunedin made its famous journey from Port Chalmers to London, inaugurating the frozen mutton trade in $1882 .{ }^{74}$ The Uruguayan government offered incentives to refrigeration as well. A law of 1885 guaranteed significant subsidies to firms that used modern procedures to export frozen meat. ${ }^{75}$ Tax exemptions were also offered on a case-by-case basis to large factories. As early as 1872, Liebig's Extract of Meat Company applied for, and was granted, permission to import machinery and coal duty-free for a decade, to encourage the renewal of its factory in Fray Bentos. ${ }^{76}$ Despite these efforts, and even if the first frozen meat factory, Frigorífica Uruguaya, started production in Montevideo in late $1904,{ }^{77}$ tasajo remained the main export staple of the Uruguayan meat industry until 1913, which made canned meat exports appear capital-intensive by comparison. ${ }^{78}$ The first of the transnational

\footnotetext{
${ }^{71}$ National Library of New Zealand, Wellington, 'The New Zealand produce trade in England: report by the Agent-General', Appendices to the Journal of the House of Representatives, 1898, H-17, p. 2.

${ }^{72}$ London Metropolitan Archives, CLA/017/LC/08/002, London Central Markets, Smithfield, Superintendent's report 1908, p. 81.

${ }^{73}$ Dirección General de Estadística, Uruguay, Censo general de 1908, Montevideo: DGE, 1912; Foreign Agricultural Service and US Department of Agriculture, Livestock and poultry: world markets and trade, Washington, DC: US Department of Agriculture, 2017.

${ }^{74}$ Susanne Freidberg, Fresh, Cambridge, MA: Belknap Press of Harvard University Press, 2009, pp. 58-61.

${ }^{75}$ José Pedro Barrán and Benjamín Nahum, Historia rural del Uruguay moderno, tomo II: la crisis económica, 1886-1894, Montevideo: Ediciones de la Banda Oriental, 1971, p. 95.

${ }^{76}$ Archivo Liebig's-Anglo, Fray Bentos, Río Negro, Uruguay, Centro Documental (henceforth ALA-CD), LEMCO-85, Constante Fontán, in representation of Liebig's Extract of Meat Company Limited, to the Contaduría General de la República.

${ }^{77}$ Alcides Beretta, La industrialización del Uruguay: cinco perspectivas históricas, Montevideo: Fundación de Cultura Universitaria, 1978, pp. 151-2.

${ }^{78}$ Luis Bértola, La industria manufacturera uruguaya, 1913-1961: un enfoque sectorial de su crecimiento, fluctuaciones y crisis, Montevideo: FCS-CIEDUR, 1991, p. 144.
} 
meat-packing corporations to arrive in the country, Swift \& Company, started producing frozen meat that year, but most of its output was still meat extract and canned beef. ${ }^{79}$ The latter was the main beneficiary of the end of tasajo's long reign, and continued to challenge the rise of frozen and chilled meats as the leading export staple until the Second World War.

\section{Energy-intensive and energy-saving meat factories}

Factor ratios in general, and access to coal in particular, hold a key part of the explanation both for New Zealand's precocity and for Uruguay's tardiness in adopting steam-powered refrigeration in meat exporting. The industry structure in New Zealand was not made in the large-scale image of the American Midwest. By 1913, there were twenty-eight freezing works in New Zealand, representing more than a third of all the meat-packing plants in the southern hemisphere, but they were comparatively small in size, and scattered throughout both islands. ${ }^{80}$ Would these small and medium-sized freezing works have made a profit if they had been faced with the coal prices prevailing in Uruguay?

That counterfactual question can be approached at a micro level by relying on firm-level data on the two single largest meat-packing factories in the two countries: the Canterbury Frozen Meat Company's plant in Belfast, near Christchurch, and Liebig's Extract of Meat Company's factory in Fray Bentos, 300 kilometres north-west of Montevideo. Both factories were surrounded by, and benefited from, a large pastoral hinterland (the Canterbury and Río Negro provinces), and had immediate access to a port suitable for long-distance shipping (Lyttleton on Pegasus Bay, and Fray Bentos on the Uruguay river), and thus led their respective countries' meat export trade. The landowners, farmers, and ranch hands breeding the bullocks and lambs in those pastoral hinterlands were connected with the global economy, not only because they were the first to create the value of the commodities that were ultimately traded on a global scale, but also because they received news of the prices of those commodities in European markets through the local press. Río Negro's $L a$ Campaña and Canterbury's Star, which both reached rural areas, published not only the financial results and slaughter statistics of the factories, but also the telegrams with the most recent prices for pastoral commodities in Liverpool and London. ${ }^{81}$

Work in cattle breeding and its main downstream industry, meat processing, was characterized by strong seasonality. I therefore compare slaughter seasons for Canterbury and Fray Bentos, which occurred between spring and autumn, when most of the plant personnel were on active duty. The scale of the factories was different, with Liebig's employing more than four times as many workers during the slaughter season, but they were both representative of the meatproducing industries of their respective countries, as the single largest factory in terms of livestock slaughtered per year. The difference in the absolute numbers of animals processed points to the fact that New Zealand's industry structure was far less concentrated than Uruguay's. Source availability made it impossible to compare the operations during the same year, but, given that technologies in meat production, maritime freight costs, and factor ratios in the economies under study did not change significantly between our two benchmark years, the comparison is still plausible. ${ }^{82}$ Comparing values also raises the issue, familiar to economic historians, of dealing with different price structures and levels. The comparison is still valid for at least two reasons. First,

\footnotetext{
${ }^{79}$ María Magdalena Camou, 'Las instituciones del mercado de trabajo en dos ramas de la industria uruguaya, 1900-1960', $\mathrm{PhD}$ thesis, Universidad de la República (Uruguay), 2010, pp. 66-7.

${ }^{80}$ Rebecca J. H. Woods, 'Breed, culture, and economy: the New Zealand frozen meat trade, 1880-1914', Agricultural History Review, 60, 2, 2012, pp. 288-308.

${ }^{81}$ Past issues of the Star can be accessed online at the National Library of New Zealand, https://paperspast.natlib.govt.nz/ newspapers (consulted 27 November 2019). All issues of La Campaña can be consulted in microfilms available at ALA-CD

${ }^{82}$ The large fall in ocean freight rates resulting from the transportation revolution occurred in the second half of the nineteenth century; both North's and Harley's indexes suggest that change was relatively small between 1895 and 1908 . The technologies available for meat production were the same at both dates, as Critchell and Raymond's extensive survey shows.
} 
Table 2. Belfast works of the Canterbury Frozen Meat Company and Fray Bentos factory of the Liebig's Extract of Meat Company, production results for the slaughter seasons of 1895 and 1908 respectively

\begin{tabular}{lccc}
\hline & Canterbury & Fray Bentos & Ratio C/FB \\
\hline Average no. of workers (non-clerical) & 350 & 1,500 & 0.23 \\
Average monthly wage (£) & 8.03 & 6.47 & 1.24 \\
Coal bought (tons) & 3,140 & 6,106 & 0.51 \\
Livestock slaughtered (LUs) & 42,247 & 162,484 & 0.26 \\
Livestock carcasses frozen (LUs) & 36,000 & 0 & - \\
Horsepower installed per worker & 1.50 & 0.40 & 3.75 \\
Tons of coal bought per worker & 9.43 & 4.07 & 2.32 \\
Coal bill ( $£$ ) & 1,670 & 7,852 & 0.21 \\
Coal bill/total wages & 0.10 & 0.18 & 0.56 \\
Tons of coal bought per 100 LUs slaughtered & 7.43 & 3.76 & 1.98 \\
\hline
\end{tabular}

Notes: livestock slaughtered were almost invariably lambs and sheep in Canterbury and calves and cows in Fray Bentos. They have been converted to livestock units (LUs) according to their land requirements as per the coefficients in Christopher S. Barnard and John S. Nix, Farm planning and control, Cambridge: Cambridge University Press, 1980, pp. 345-6. An LU of 1 represents a mature dairy cow. Values in Uruguayan pesos were converted to sterling using the gold standard exchange rate prevailing at the time.

Sources. For Canterbury: 'The Canterbury land district', New Zealand Statistical Yearbook 1894; Star (Canterbury), issue 5237, 1 June 1895. For Fray Bentos: Dirección General de Estadística, Censo general de 1908, pp. 1191 and 1209; Anuario estadístico, 1909-10, p. LXXVIII; and ALA-CD, 'Libro de importaciones, 1908-1912'. Coal bill calculated on the basis of the coal prices shown in figure 2.

both countries were on the gold standard, which in the period before the First World War was characterized by low average inflation rates, which somewhat curbs the problem of changing price levels. Second, and more importantly, the key aspects in this firm-level comparison are relative to their own price structure rather than absolute price levels (the impact of the coal bill compared to wage costs, and the profit margin of each factory), and are therefore not affected by the problem of changing price levels.

I use the dataset for minimum wholesale coal prices (introduced in the second section) to estimate the coal bill of each factory (table 2). Given that in New Zealand the meat industry concentrated on mutton, whereas in Uruguay it focused on beef, I standardize the number of animals using livestock units (LUs), following the coefficients provided by Barnard and Nix. ${ }^{83}$ In open-air grazing systems, as New Zealand's and Uruguay's, LUs calculated in this way usefully reflect the acreage of pastureland required to feed the bullocks and lambs destined for the killing floor, revealing the material realities of the production process as a whole, and allowing a better understanding of the factor biases in meat production.

The Canterbury freezing works were far more energy- and capital-intensive than the production of salted meat, canned beef, and beef extract that was carried out in Fray Bentos: installed capacity per worker was more than three times higher, and coal usage per worker was more than twice as high. Conversely, the Fray Bentos production was comparatively land-extensive and energy-saving: the ratio of tons of coal per LU slaughtered was about half of Belfast's, LUs being a proxy for the pastoral land required to raise the livestock. ${ }^{84}$ As a result of its workers being powered by less inanimate energy, the Fray Bentos factory also seems labour-intensive in the comparison. Finally, average wages were lower in Fray Bentos, by an almost identical margin to the GDP per capita differential separating the two countries. ${ }^{85}$ All these ratios at the firm level bear

\footnotetext{
Douglass North, 'Ocean freight rates and economic development 1730-1913', Journal of Economic History, 18, 4, 1958, pp. 537-55; Harley, 'Ocean freight rates'; Critchell and Raymond, History of the frozen meat trade.

${ }^{83}$ Christopher S. Barnard and John S. Nix, Farm planning and control, Cambridge: Cambridge University Press, 1980, pp. 345-6.

${ }^{84}$ Each livestock species, kind, and age group requires a different average acreage, which is expressed in their livestock unit coefficient.

${ }^{85}$ According to the Maddison Project Database (2018 update), https://www.rug.nl/ggdc/historicaldevelopment/maddison/ releases/maddison-project-database-2018 (consulted 27 November 2018), New Zealand's per capita GDP in 1895 was $23 \%$ higher than Uruguay's in 1908.
} 
Table 3. Canterbury Frozen Meat Company's cash flow in 1894 and counterfactual applying Uruguayan coal prices

\begin{tabular}{lrr}
\hline & Canterbury & Counterfactual \\
\hline Factory workers' wages $(£)$ & 16,338 & 16,338 \\
Wear, tear, and depreciation ( $£$ ) & 3,000 & 3,000 \\
Director's fees, clerical staff, office rent, and tax (£) & 2,179 & 2,179 \\
Coal bill $(£)$ & 1,670 & 3,749 \\
Insurance $(£)$ & 478 & 478 \\
All other costs (shipping, curing, preserving) (£) & 7,408 & 7,408 \\
Total sales $(£)$ & 33,504 & 33,504 \\
Net profit $(£)$ & 2,447 & 352 \\
Rate of dividend upon capital & $8 \%$ & $1 \%$ \\
\hline
\end{tabular}

Sources: Canterbury Frozen Meat Company's annual accounts published in Press, issue 8748, 21 March 1894. Counterfactual constructed using Uruguayan coal prices presented in figure 2 .

similarities with those at the macro, economy-wide level. Uruguay had more pastoral land, more livestock, and a slightly larger population, but worse conditions of access to coal. Modern energy shows in this comparison its long-term characteristics: strong complementarity with capital and a bias towards saving labour and land. ${ }^{86}$ Finally, it should be noted that the coal bill relative to the labour costs was much higher in Fray Bentos than in Canterbury, which suggests that, had coal been cheaper in Uruguay, Liebig's could have used more energy-intensive technologies.

Arguments in history are often implicitly counterfactual, even if we do not always admit to it. In comparative history it is sometimes useful to turn implicit counterfactual statements into explicit questions: what would have happened if the Canterbury freezing works had faced the coal prices prevailing in Uruguay at the time? That is ultimately the only way to test hypotheses that argue that relative prices of inputs affected choices of techniques and the adoption of technology. In this sense, the critics of coal as a relevant factor behind the initial locations of modern economic growth have pointed out that showing coal price differentials is not enough, since producers cared about total costs, not individual input prices, and the energy bill represented a comparatively small share of costs. ${ }^{87}$ Those arguments hold in part for the present case, as the minimum coal bill represented about $7 \%$ of the total costs at the Canterbury works in $1895 .{ }^{88}$ Nevertheless, given the necessary nature of coal for frozen meat production in this period, and the fact that it could not feasibly be substituted by other energy carriers, a significant change in coal prices would have greatly affected dividends, since consuming less coal was not an option. According to its accounts, published in the contemporary press, the Canterbury Frozen Meat Company's dividends in 1895 would, other things being equal, have decreased from about $8 \%$ to $1 \%$, had it bought coal at the minimum estimated wholesale price in Uruguay (table 3).

As the New Zealand-Uruguay comparison illustrates, when factor ratios and political conditions make wages comparatively high and inelastic, and geography and technology make transport costs expensive, an increase in the price of energy can render the whole operation unprofitable. Because of their scale, even if they were highly specialized in a handful of commodities, both economies can be considered 'small countries', in the sense that trade economists give to the term, so that they could not affect the international prices of their main export commodities. In such settings, profit margins and the incentive to innovate did depend on the conditions of access to coal, even if that access did not represent a quantitatively large part of total costs. In the Uruguayan case, it made sense for individual firms to continue to specialize in meat extract, canned meat, and beef jerky in the short term, even if this resulted in lost opportunities from

\footnotetext{
${ }^{86}$ Paul Warde, 'Energy and industrial growth', in Kander, Malanima, and Warde, Power to the people, pp. 219-27.

${ }^{87} \mathrm{An}$ articulate summary of such arguments can be found in McCloskey, Bourgeois dignity, pp. 186-96.

${ }^{88}$ These are my own calculations, based on data on the Canterbury works taken from 'The Canterbury land district', New Zealand Statistical Yearbook 1894, and the Star (Canterbury), issue 5237, 1 June 1895, available at the National Library of New Zealand.
} 
an economy-wide and long-term perspective. Indeed, Liebig's Extract of Meat Company had one of the best profit records of any British company in Latin America. ${ }^{89}$

Thinking in terms of staple theory, from the perspective of economic development, specializing in frozen meat is not only better than specializing in canned beef because of its higher income elasticity of demand, but also because of its linkages and spill-over effects. ${ }^{90}$ The relative lag of about three decades between the adoption of frozen meat as the leading export in the industry in Uruguay, compared to New Zealand, holds part of the key to the persistence of the income gap between these two small settler economies during the era of export-led growth in the late nineteenth and early twentieth centuries. In turn, coal prices contribute to explaining why New Zealand, a country with fewer livestock in absolute and relative terms, and less natural pasture, became a leader in the frozen meat trade, whereas Uruguay, the most cattle-abundant country in the world, was a latecomer to the industry.

\section{Conclusion}

Geographically distant, New Zealand and Uruguay were in some sense neighbours, as their agrarian produce shared and competed for ocean liners, market stalls, and pantry shelves. They were also linked through more direct, South-South, economic and environmental connections: Uruguayan grass seeds were grown in New Zealand, from where Corriedale sheep were shipped to the River Plate to produce 'Montevideo wool', using presses made in Wairarapa. ${ }^{91}$ This kind of mutual intervention would render the comparison invalid if it were defined in terms of a 'natural experiment', because each 'experiment' should be wholly independent from the other. In history, however, societies are not confined to Petri dishes, so comparisons must sometimes be made in the context of connections. Indeed, as the literature on histoire croisée and 'entangled histories' argues, that is often the only way to do it. ${ }^{92}$ When seen through such a lens, late nineteenth-century New Zealand and Uruguayan workers on the grazing range, as well as the killing floor, and the ruminants who made the journey between them, emerge as part of the same global history. Their part in that history was fundamentally shaped by grass, a feature of their landscapes that is sometimes taken for granted, but that was indisputably their main crop. ${ }^{93}$

This article has argued that the conditions of access to coal contributed to shaping the way in which New Zealanders and Uruguayans worked their grass and their animals during the First Globalization, when terms of trade favoured temperate agricultural producers and, in so doing, fashioned production techniques, export structures, and development paths. Large-scale hydropower and national electrical grids would later make coal prices irrelevant for refrigerated meat

\footnotetext{
${ }^{89}$ Liebig's annual dividend by 1900 was about $20 \%$, according to Winn's study of the company books. Winn, 'British informal empire', pp. 119-20.

${ }^{90}$ Melville H. Watkins, 'A staple theory of economic growth', Canadian Journal of Economics and Political Science/Revue Canadienne d'Economique et de Science Politique, 29, 2, 1963, pp. 141-58. For a recent historiographical review and an attempt to refine the theory, see Morris Altman, 'Staple theory and export-led growth: constructing differential growth', Australian Economic History Review, 43, 3, 2003, pp. 230-55.

${ }^{91}$ Eric Pawson and Vaughan Wood, 'The grass seed trade', in Brooking and Pawson, Seeds of empire, p. 121; Nicholas Twohill, 'The British world and its role in the relationship between New Zealand and the southern cone countries of South America, 1820-1914', Historia (Santiago), 43, 1, 2010, p. 156; Richard Wolfe, A short history of sheep in New Zealand, Auckland: Random House New Zealand, 2006, p. 68.

${ }^{92}$ Michael Werner and Bénédicte Zimmermann, 'Beyond comparison: histoire croisée and the challenge of reflexivity', History and Theory, 45, 1, 2006, pp. 30-50; Shalani Randeria, 'Entangled histories of uneven modernities: civil society, caste solidarities and legal pluralism in post-colonial India', in Yehuda Elkana, Ivan Krastev, Elisio Macamo, and Shalini Randeria, eds., Unraveling ties: from social cohesion to new practices of connectedness, Frankfurt: Campus Verlag, 2002, pp. 284-311.

${ }^{93}$ This has led historians to define these societies with terms such as 'livestock civilization' and 'grass monoculture economy'. Barrán and Nahum, Agricultura, pp. 177-99; Geoff Bertram, ‘The New Zealand economy, 1900-2000', in Giselle Byrnes, ed., The new Oxford history of New Zealand, Melbourne: Oxford University Press, 2009, p. 540.
} 
production, but by then the tail winds of the First Globalization had turned, and the window of opportunity for peripheral agricultural export economies was closing.

Economic development in New Zealand and Uruguay during the First Globalization (and elsewhere in the periphery where a transition to modern economic growth developed through export agriculture) was not merely a mechanical response to increasing Western demand for foodstuffs. Nor was it a foregone conclusion of technological breakthroughs in the productive and transportation uses of steam power, necessary though these were to defeat the tyranny of distance. ${ }^{94}$ By looking at the material reality of meat production and preservation in New Zealand and Uruguay, and comparing relative prices and costs in that context, this article has argued that the way in which supply responded to international demand was shaped in each country by its specific natural resources, and by their conditions of access to modern energy. Those responses, interacting with socially constructed institutions and constraints, led to different choices of productive technique, industry structures, and specialization patterns.

The results presented here will hopefully encourage more comparisons to further discuss the role of coal beyond Western industrialization, its traditional realm in economic historiography. Relating specifically to our two cases, if the estimates on coal supply and prices are reasonably good, they could spark further research into the ecological consequences of the development of rural capitalism in New Zealand and Uruguay, small countries where environmental change can arguably be more easily traced in the historical record. More generally, the results presented here suggest that nature's role in past (and present) economic development is lost by reducing it to 'natural capital', as the environment's economic contributions cannot always be tallied, aggregated, and compared with other assets. 'Natural resource abundance', or 'land abundance', does not mean any one thing, because resources are specific and interact with each other: coal and grass in New Zealand produced a different outcome than grass alone did in Uruguay.

Emiliano Travieso is a PhD candidate at King's College, Cambridge and a member of the Cambridge Group for the History of Population and Social Structure (CAMPOP). He is interested in Latin American, comparative, and global economic history, focusing on agriculture and natural resources. His doctoral research centres on the relationships between economic development and the environment in Uruguay before 1914.

\footnotetext{
${ }^{94}$ The expression was popularized by Blainey in his history of Australia. Geoffrey Blainey, The tyranny of distance: how distance shaped Australia's history, Melbourne: Macmillan, 1968.
}

Cite this article: Travieso E. 2020. United by grass, separated by coal: Uruguay and New Zealand during the First Globalization. Journal of Global History 15: 269-289, doi:10.1017/S1740022820000042 